\title{
Экспериментальная оценка возможностей применения рамановской спектроскопии для оптимизации режима высокотемпературной обработки углеродных волокон на основе полиакрилонитрила
}

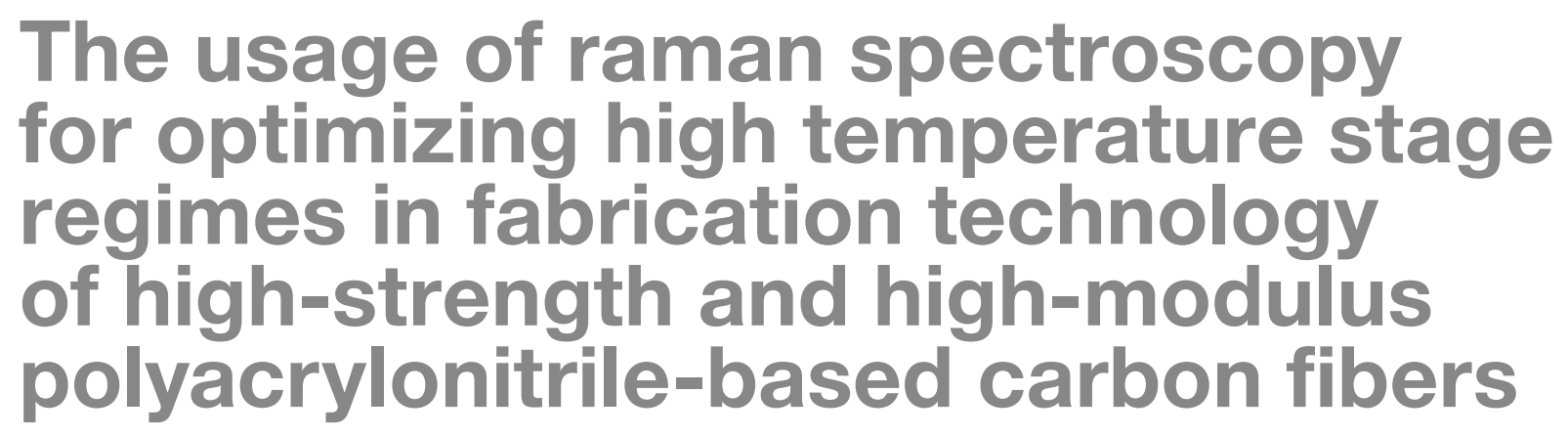

В. М. Самойлов, М. А. Осмова, А. В. Находнова, Е. И. Тимощук, А. Б. Вербец, А. Н. Бубненков,

Н. Н. Степарёва, А. Р. Гареев, А. А. Шевцов, Н. Г. Бардин Акционерное общество «Научно-исследовательский институт конструкционных материалов на основе графита «НИИграфит», Москва, Россия

\author{
V. M. Samoilov, M. A. Osmova, A. V. Nakhodnova, \\ E. I. Timoshchuk, D. B. Verbets, A. N. Bubnenkov, \\ N. N. Steparyova, A. R. Gareev, A. A. Shevtsov, N. G. Bardin \\ JSC Scientific research Institute \\ of graphite-based structural materials "NIIgrafit", \\ Moscow, Russia
}

Поступила в редакцию 06.05.2020, принята к печати 11.07.2020

\section{Абстракт}

Углеродные волокна (УВ) на основе полиакрилонитрила (ПАН), полученные в результате термообработки от 1000 до $3000^{\circ} \mathrm{C}$, исследовали методом рамановской спектроскопии и рентгеноструктурного анализа. Приведены данные о прочности и модуле упругости экспериментальных образцов углеродных волокон (УВ) на основе ПАН в зависимости от температуры обработки в интервале температур от 1000 до $3000^{\circ} \mathrm{C}$ и скорости протяжки через нагреватель от 10 до 300 м/ч. Приведены зависимости, показывающие, что при повышении температуры термообработки (ТТО) параметр $I_{D} / I_{G}$ (соотношение интегральных интенсивностей спектральных линий $D$ и $G$ ), а также полуширина линии $G$, измеренная на полувысоте (параметр $\left.\Gamma\left(\omega_{G}\right)\right)$, снижаются, что связано с ростом размеров кристаллитов вдоль оси волокна. После достижения ТТО порядка $2000^{\circ} \mathrm{C}$, в рамановском спектре появляется $2 \mathrm{D}$ линия, и наблюдается рост параметра $I_{2 D} / I_{G}$ (соотношение интегральных интенсивностей спектральных линий $2 D$ и $G$ ) с ростом TTO, что также связано с ростом степени совершенства кристаллической структуры. При этом $I_{D} / I_{G}$ хорошо коррелирует с модулем упругости филаментов УВ.

Однако, при фиксированной ТТО $3000^{\circ} \mathrm{C}$, повышение скорости протяжки от 10 до 300 м/час приводило к снижению прочности, модуля упругости и плотности УВ, а также к увеличению диаметра филаментов. При этом кристаллическая структура поверхностных слоёв филаментов, характеризуемая методом рамановской спектроскопии, оставалась практически одинаковой.

Методом рентгеноструктурного анализа было показано, что филаменты УВ, полученного при высоких скоростях протяжки содержат структурные составляющие, различающиеся по степени совершенства кристаллической структуры. Подтверждается, что радиальная неоднородность филаментов, характеризуемая параметрами $I_{D} / I_{G}$ и $\Gamma\left(\omega_{G}\right)$, возрастает с увеличением скорости протяжки, причём структурные составляющие с меньшей степенью совершенства кристаллической структуры локализуются в области ядра филамента, что и является причиной снижения прочности и модуля упругости.

\footnotetext{
Abstract

Polyacrylonitrile-based (PAN) carbon fibers (CFs) processed at temperatures ranging from 1000 to $3000^{\circ} \mathrm{C}$ are studied with the Raman spectroscopy and X-ray diffraction methods. The relationships of tensile strength and Young modulus for experimental specimens of PAN-based CFs from heat treatment temperature (HTT) from 1000 to $3000^{\circ} \mathrm{C}$ and draw speed through the heater from 10 to $300 \mathrm{~m} / \mathrm{hr}$ are provided. It is shown that the $I_{D} / I_{G}$ parameter (the ratio of the integral intensities of the $D$ and $G$ spectral bands) and full width at half maximum of spectral band $G$ (the $\Gamma\left(\omega_{G}\right)$ parameter) decrease with the increase of $\mathrm{HTT}$, caused by crystallite growth along the fiber axis. Beyond the $2000^{\circ} \mathrm{C}$ temperature threshold, appearance of the $2 \mathrm{D}$ spectral band in Raman spectra and growth of the $I_{2 \mathrm{D}} / I_{\mathrm{C}}$ parameter (the ratio of the integral intensities of the $2 D$ and $G$ spectral bands) are observed, caused by the growth of degree of perfection of crystalline structure. A high degree of correlation between the $I_{D} / I_{G}$ parameter and Young modulus is observed.

However, at fixed heater temperature of $3000^{\circ} \mathrm{C}$, increasing the draw speed from 10 to $300 \mathrm{~m} / \mathrm{hr}$ has led to a decrease in tensile strength, Young modulus and density of CFs, and to the growth of filament diameter. The crystalline structure of filament surface layers characterized by Raman spectroscopy remained mostly unchanged.

X-ray diffraction analysis demonstrates an appearance of structural components of CF filaments obtained at high draw speeds that differ in crystalline structure. A validation of an increase of radial heterogeneity of filaments, characterized by the $I_{D} / I_{G}$ and $\Gamma\left(\omega_{G}\right)$ parameters, with the increase of draw speed is obtained. Furthermore, it is shown that structural components with a lesser degree of perfection of crystalline structure are localized in the filament core, which causes the decrease in tensile strength and Young modulus.
} 